\title{
Kepekaan terhadap Humor berhubungan dengan Tingkat Kecemasan Mahasiswa Fakultas Kedokteran Saat Menghadapi Ujian
}

\author{
Muhammad Yusuf Karim ${ }^{1}$, Suyatmi², Zulaika Nur Afifah ${ }^{3}$ \\ 1.Program Studi Kedokteran, Fakultas Kedokteran Universitas Sebelas Maret \\ 2.Departemen Histologi Fakultas Kedokteran Universitas Sebelas Maret \\ 3.Unit Pendidikan Kedokteran Fakultas Kedokteran Universitas Sebelas Maret
}

Korespondensi : muhammadyusufkarim@gmail.com

\begin{abstract}
ABSTRAK
Pendahuluan: Mahasiswa kedokteran menghadapi ujian blok sebagai bentuk evaluasi hasil pembelajaran dalam setiap bloknya. Ujian blok bagi mahasiswa kedokteran terutama mahasiswa baru dapat memicu kecemasan. Kecemasan yang tidak terkendali dapat mempengaruhi prestasi belajar. Dibutuhkan suatu mekanisme pertahanan diri dalam mengatasi kecemasan. Salah satu mekanisme pertahanan diri yang dapat mengatasi kecemasan adalah kepekaan terhadap humor. Tujuan penelitian ini adalah untuk mengetahui apakah terdapat hubungan antara kepekaan terhadap humor dengan tingkat kecemasan saat menghadapi ujian.

Metode: Rancangan penelitian ini adalah observasional analitik dengan pendekatan cross sectional. Subjek penelitian adalah mahasiswa Tahun Pertama Program Studi Kedokteran Universitas Sebelas Maret. Sampel diambil secara simple random sampling. Jumlah sampel penelitian ini 152 orang. Kepekaan terhadap humor diukur menggunakan Multidimensional Sense of Humor Scale (MSHS) dan tingkat kecemasan diukur menggunakan Taylor Manifest Anxiety Scale (TMAS). Data yang terkumpul dianalisis menggunakan Uji Korelasi Pearson.

Hasil: Penilaian kepekaan terhadap humor dan tingkat kecemasan didapatkan rata-rata nilai kepekaan terhadap humor $69,90 \pm 7,22$ dan tingkat kecemasan 22,16 $\pm 6,93$. Karakteristik sampel menunjukkan 78,3\% memiliki kepekaan terhadap humor yang tinggi dan $21,7 \%$ memiliki kepekaan terhadap humor sedang. Pengukuran tingkat kecemasan menunjukkan 50,7\% tergolong cemas dan 49,3\% tergolong tidak cemas. Pada uji korelasi Pearson didapatkan nilai $\mathrm{r}=-0,263$ dan nilai $\mathrm{p}=0,001$

Kesimpulan: Terdapat korelasi negatif antara kepekaan terhadap humor dengan tingkat kecemasan mahasiswa kedokteran tahun pertama dalam menghadapi ujian.
\end{abstract}

Kata kunci: kepekaan terhadap humor,tingkat kecemasan, mahasiswa kedokteran

ABSTRACT

Background:Medical students are facing examination in each topics to evaluate learning achievement. An examination could be a trigger for anxiety. Uncontrolled anxiety could affect the learning achievement. Coping mechanism is needed to decrease the anxiety level. One of the coping mechanisms to decrease anxiety level is sense of humor. The aim of this study was to evaluate whether sense of humor could affect the anxiety level.

Methods:This was an observational analytic with cross-sectional design study.The subjects were First Year Medical Students of Universitas Sebelas Maret. The sample was collected by simple random sampling method. Sense of Humor was assesed using Multidimensional Sense of Humor Scale (MSHS). Anxiety level was assesed using Taylor 


\begin{abstract}
Manifest Anxiety Scale (TMAS). Collected data was analyzed with Kolmogorov-Smirnov Normality Test and Pearson Correlation Test.

Results: There were 152 samples in this study. The mean of sense of humor and anxiety level were $69.90 \pm 7.22$ and $22.16 \pm 6.93$ respectively. The majority of the samples showed that $78.3 \%$ had a high sense of humor, while $21.7 \%$ had a moderate sense of humor. More than half of the samples (50.7\%) were anxious and $49.3 \%$ were not anxious. The result of the Pearson correlation test showed $r=-0.263$ and $p=0.001$.

Conclusions:This study indicates a negative correlation between sense of humor and anxiety level towards examination on First Year Medical Student of Universitas Sebelas Maret.
\end{abstract}

Keywords: sense of humor, anxiety level, examination

\section{PENDAHULUAN}

Keberhasilan pencapaian tujuan pendidikan sangat bergantung pada proses belajar yang dialami oleh peserta didik $^{1}$. Keberhasilan proses belajar juga dipengaruhi oleh kondisi psikologi, yang salah satunya adalah kecemasan ${ }^{2}$. Dalam hal ini salah satu rangsang yang membangkitkan kecemasan adalah situasi saat menghadapi tes atau ujian ${ }^{3}$.

Kecemasan merupakan sebuah keadaan khawatir terhadap sesuatu hal buruk yang akan segera terjadi. Hal-hal yang dicemaskan misalnya adalah kesehatan, relasi sekolah, ujian dan kondisi lingkungan. Kecemasan adalah suatu sinyal yang menandakan pada diri seseorang tentang adanyabahaya yang mengancam dan memungkinkan seseorang mengambil tindakan untuk mengatasi ancaman tersebut ${ }^{4}$.

Mahasiswa merupakan salah satu contoh kelompok masyarakat yang mudah cemas. Mahasiswa kedokteran merupakan kelompok mahasiswa yang memiliki stressor tinggi, terutama bagi mahasiswa baru ${ }^{6}$. Dalam proses pembelajaran, mahasiswa dihadapkan dengan kendala- kendala, diantaranya adalah kesulitan mencari literatur, kurangnya minat mahasiswa dalam belajar serta kurang memahami materi yang telah dibaca. Hal tersebut sangat berpotensi menyebabkan kecemasan ${ }^{7}$.
Proses kecemasan seseorang dalam menghadapi stressor dapat diatasi melalui berbagai coping mechanism atau mekanisme pertahanan diri. Salah satu cara yang dipakai adalah dengan mengembangkan humor. Untuk dapat mengamati, merasakan, atau mengungkapkan humor, seseorang memerlukan kepekaan terhadap humor (Sense of Humor) ${ }^{8}$. Kepekaan terhadap humor merupakan sesuatu kemampuan seseorang untuk menikmati, mengamati, dan mengekspresikan sesuatu hal yang lucu? Individu dengan kepekaan terhadap humor yang lebih tinggi, lebih termotivasi, lebih ceria, dapat dipercaya dan mempunyai selfesteem yang lebih tinggi sehingga kemampuan dalam mengatasi kecemasan pun akan lebih baik ${ }^{8}$. Penelitian ini bertujuan untuk mengetahui adakah hubungan kepekaan terhadap humor dengan tingkat kecemasan mahasiswa saat menghadapi ujian blok di Fakultas Kedokteran Universitas Sebelas Maret.

\section{METODE}

Penelitian ini merupakan jenis penelitian observasional analitik dengan pendekatan cross sectional. Penelitian dilakukan pada bulan September hingga Desember 2015 di Fakultas Kedokteran Universitas Sebelas Maret. Populasi sumber pada penelitian ini adalah seluruh mahasiswa 
Karim et.al., Kepekaan terhadap Humor berhubungan dengan Tingkat Kecemasan Mahasiswa Fakultas Kedokteran Saat Menghadapi Ujian

tahun pertama Program Studi Kedokteran Universitas Sebelas Maret. Teknik pengambilan sampel penelitian ini dilakukan dengan simple random sampling.Rumus besar sampel yang digunakan untuk penelitian ini menggunakan rumus Slovin ${ }^{10}$, dan didapatkan besar sampel dalam penelitian sebesar 152 mahasiswa.

Kepekaan terhadap humor dapat diukur dengan Multidimensional Sense of Humor Scale (MSHS) yang dikembangkan oleh Thorson dkk yang memiliki korelasi uji reliabilitas $\alpha$ Chronbachsebesar $0,912^{11}$ dan diterapkan dalam penelitian Febriana ${ }^{12}$. Tingkat kecemasan diukur dengan Taylor Manifest Anxiety Scale(TMAS) ${ }^{13}$. Data yang terkumpul dianalisis menggunakan $\mathrm{Uji}$ Korelasi Pearson.

\section{HASIL}

Dari pengukuran kepekaan terhadap humor dan tingkat kecemasan pada subjek penelitian didapatkan data 152 sampel terdiri dari 44 responden laki-laki dan 108 responden perempuan. Berdasarkan jenis kelamin didapatkan bahwa responden perempuan lebih banyak yang masuk kategori cemas yaitu sebanyak 53,70\%. Sedangkan pada responden pria justru lebih banyak yang masuk kedalam kategori tidak cemas yaitu $56,82 \%$.

Tabel 1. Persentase responden dalam hal kepekaan terhadap humor dan tingkat kecemasan

\begin{tabular}{llrr}
\hline & Variabel & $\mathrm{N}$ & $(\%)$ \\
\hline KTH & & & \\
& Rendah & 0 & $0 \%$ \\
& Sedang & 33 & $21,7 \%$ \\
& Tinggi & 119 & $78,3 \%$ \\
& Total & 152 & $100 \%$ \\
\hline TK & & & \\
& Tidak cemas & 75 & $49,3 \%$ \\
& Cemas & 77 & $50,7 \%$ \\
& Total & 152 & $100 \%$ \\
\hline
\end{tabular}

Keterangan : KTH= Kepekaan terhadap Humor; TK= Tingkat Kecemasan; N= Jumlah
Karakteristik data yang tersaji pada Tabel 1 menunjukkan bahwa mayoritas responden (78,3\%) memiliki kepekaan terhadap humor yang tinggi. Berdasarkan kategori kecemasan didapatkan bahwa mayoritas $(50,9 \%)$ responden tergolong cemas. Karakteristik rerata data dapat dilihat pada Tabel 2.

Tabel 2. Rerata kepekaan terhadap humor dan tingkat kecemasan

\begin{tabular}{lr}
\hline Variabel & Rerata \pm SD \\
\hline KTH & $69,90 \pm 7,22$ \\
TK & $22,16 \pm 6,93$ \\
\hline
\end{tabular}

Keterangan : KTH= Kepekaan Terhadap Humor; $\mathrm{TK}=$ Tingkat Kecemasan; $\mathrm{N}=$ JumlahSampel; $\mathrm{SD}=$ Standard Deviation

Hasil uji korelasi Pearson, seperti yang ditampilkan pada tabel 2 menunjukkan bahwa antara kepekaan terhadap humor dan tingkat kecemasan terdapat hubungan negatif dengan nilai kekuatan hubungan -0,263 yang menunjukkan kekuatan hubungan lemah, sehingga dapat dikatakan bahwa semakin tinggi kepekaan terhadap humor, maka semakin rendah tingkat kecemaannya. Nilai $\mathrm{p}$ $=0,001$ menunjukkan bahwa penelitian ini menunjukkan korelasi yang signifikan antara kepekaan terhadap humor dan tingkat kecemasan. Dengan kata lain, terdapat korelasi lemah yang bermakna secara statistik antara kepekaan terhadap humor dan tingkat kecemasan pada mahasiswa tahun pertama saat menghadapi ujian blok di Fakultas Kedokteran Universitas Sebelas Maret.

\section{PEMBAHASAN}

Pada penelitian ini didapatkan nilai korelasi $r=-0,263$. Nilai ini menunjukkan kekuatan korelasi yang lemah. Korelasi yang lemah dalam penelitian ini dapat dipengaruhi oleh variasi bentuk mekanisme pertahanan diri seseorang terhadap kecemasan. Setiap orang memiliki kecenderungan bentuk mekanisme pertahanan diri yang berbeda-beda dalam menghadapi kecemasan. Pada dasarnya 
pencegahan kecemasan dalam menghadapi stres kehidupan dapat dilakukan dengan penyesuaian diri berorientasi pada tugas serta pembelaan ego ${ }^{14}$.

Dari hasil analisis data, didapatkan hubungan yang bermakna secara statistik antara kepekaan terhadap humor dan tingkat kecemasan pada mahasiswa tahun pertama saat menghadapi ujian blok di Fakultas Kedokteran Universitas Sebelas Maret.Hasil penelitian ini sesuai dengan beberapa hasil penelitian yang menyatakan bahwa kepekaan terhadap humor akan berhubungan dengan tingkat kecemasan, melalui uraian bahwa kejadian kecemasan perlu diatasi dengan mekanisme pertahanan diri. Salah satu mekanisme pertahanan diri terhadap kecemasan adalah kepekaan terhadap humor ${ }^{6-}$ $8,18,19$

Hasil penelitian ini juga sesuai dengan penelitian yang dilakukan oleh Srivastava dan Maurya $^{20}$ yang menyatakan bahwa kepekaan terhadap humor memiliki fungsi sebagai mekanisme pertahanan diri terhadap kecemasan. Selain itu, hasil penelitian ini juga sesuai dengan penelitian Zulkarnaen dan Novliadi ${ }^{21}$ yang menyatakan adanya hubungan negatif antara sense of humor dengan kecemasan di kalangan mahasiswa psikologi Universitas Sumatera Utara.

Penelitian ini memiliki beberapa keterbatasan, diantaranya masih terdapat variabel luar tak terkendali yang kemungkinan dapat mempengaruhi hasil penelitian. Variabel luar tak terkendali dalam penelitian ini adalah ras, minat dan motivasi. Perbedaan ras, minat dan motivasi dapat mempengaruhi kecenderungan kecemasan seseorang ${ }^{22-24}$. Namun pada penelitian ini, variabel luar tak terkendali tersebut tidak di observasi oleh peneliti. Bentuk keterbatasan yang lain pada penelitian ini yaitu penilaian variabel masih terbatas pada satu ujian blok saja sehingga kemungkinan belum dapat menggambarkan karakteristik variabel pada blok yang lainnya.

Bentuk mekanisme pertahanan diri terhadap kecemasan dapat dilakukan berdasarkan pendekatan agama dan pendekatan melakukan aktivitas fisik teratur, dimana hal-hal tersebut dapat mengurangi kecemasan ${ }^{15-17}$. Oleh karena itu, peneliti berasumsi bahwa nilai korelasi yang lemah dalam penelitian ini dapat dipengaruhi oleh variasi bentuk mekanisme pertahanan diri terhadap kecemasan tersebut.

\section{KESIMPULAN}

Terdapat korelasi negatif antara kepekaan terhadap humor dengan tingkat kecemasan mahasiswa kedokteran tahun pertama dalam menghadapi ujian blok di Fakultas Kedokteran Universitas Sebelas Maret.

\section{UCAPAN TERIMA KASIH}

Penulis mengucapkan terimakasih kepada Dr. Eti Poncorini Pamungkasari dr., MPd, Muthmainah, dr., M.Neurosci, dan Balgis dr., M.Sc, CM, FM yang telah memberikan bimbingan, kritik, dan saran yang sangat membantu selama penelitian hingga penulisan naskah publikasi ini.

\section{DAFTAR PUSTAKA}

1. Suwardi, D.R. Faktor-faktor yang mempengaruhi hasil belajar siswa kompetensi dasar ayat jurnal penyesuaian mata pelajaran akuntansi kelas xi ips di sma negeri 1 kudus. Economic Education Analysis Journal 2012. 1:2

2. Slameto. Belajar dan Faktor-Faktor yang Mempengaruhinya. Jakarta: Rineka Cipta; 2010. p: 54

3. Djiwandono, SE. Psikologi Pendidikan. Jakarta: PT Grasindo; 2002.

4. Nevid JS. Psychology: concepts and applications. Boston: Houghton Mifflin; 2003. 
5. Tartakovsky M. Depression and Anxiety Among College

Studentsdalamhttp://psychcentral.com/lib /2008/depression-and-anxiety-amongcollege-students/2008[ cited3 Agustus 2015].

6. Moffat K.J., McConnachie., Ross S., dan Morrison J. First Ylyear medical student stress and coping in a problem-based learning medical curriculum. Journal of Medical Education; 2004. 38: 459-577

7. Selenthin AL. Medical students' attitudes towards group and self-regulated learning. International Journalof MedicalEducation; 2012.3:46-56

8. Kelly, W.E. An investigation of worry and sense of humor. Journal of Clinical Psychology.2002. 136: 657-666.

9. Martin, R.A. Sense of humor: Positive psychological asessment: a handbook of models and measures. Washington, DC: American

Psychological Association.2003.

10. Notoatmodjo. Metodologi penelitian kesehatan. Jakarta: Rineka Cipta. 2010.

11. Thorson J.A., Powell F.C., Schullet I.S., dan Hampes W.P. Psychological health and sense of humor. Journal of Clinical Psychology. 1997. 53(6). 605-619.

12. Febriana I. Pengaruh kepribadian dan sense of humor terhadap psychological well-being. Jakarta: Universitas Islam Negeri Syarif Hidayatullah. 2014.

13. Hakim L. Hubungan kecemasan dengan motivasi berprestasi pada mahasiswa pendidikan dokter semester III universitas sebelas maret. Surakarta :Fakultas Kedokteran Universitas Sebelas Maret. 2013.

14. Maramis W.F. dan Maramis A.A. Catatan ilmu kedokteran jiwa. Edisi 2.Surabaya :Airlangga Universitas Press. 2009. pp : 308-312.

15. Safara M danBathia MS. Relationship of religious beliefs with anxiety and depression. Delhi Psychiatry Journal. 2008. 11(2): 177-179

16. Larun L, Nordheim LV, Ekeland E, Hagen KB, Heian F. Exercise in prevention and treatment of anxiety and depression among children and young people. Cochrane Database and Systemic Reviews. 2006.

17. Tanzini E. Health,wellbeing, and academic achievement among urban college students.City College of New York.2015.

18. Jadoon NA, Yaqoob R, Raza A, Shehzad MA, Choudry ZS. Anxiety and Depression among Medical Students: a cross-sectional study. Journal of Pakistan Medical Association. 2010. 60(8):699702

19. Martin, R.A. The Psychology of humor: Introgative approach. London: Elsevier.2007.

20. Srivastava U.R. danMaurya V. Sense of humor and psychological health among health care professionals. Indian Journal of Positive Psychology. 2014.p 376-381.

21. Zulkarnaen dan Novliadi. Sense of humor dan kecemasan menghadapi ujian di kalangan mahasiswa. Jurnal Majalah Kedokteran Nusantara. 2009. 42:1

22. Chapman LK dan Steger MF. Race and religion: Differential prediction of anxiety symptoms by religioun coping in africanamerican and europianamerican young adults. Journal of Anxiety and Depression Assosiation of America. 2010. 27:316-322.

23. Wu C, Erickson SR, Pharm D, Piette JD, Balkrishnan R. The association of race, comorbid anxiety, and antidepressant adherence among medicaid enrollees with major depressive disorder. Research in Social and Administrative Pharmacy.2012. 193-205

24. Tsai C dan Chang I. The study on motivation and anxiety of english learning of students at a taiwan technical university. International Journal of English Language Teaching.2013. 1(1). 24-41 